\title{
The Impact of Monetary Inflation on Investment Decisions in Jordanian Industrial Companies
}

\author{
Marwan Mohamed Abu Orabi ${ }^{1}$ \\ ${ }^{1}$ Associate Professor, International Islamic Science University, Jordan \\ Correspondence: Marwan Mohamed Abu Orabi, Associate Professor, International Islamic Science University, \\ Jordan. E-mail: drmarwan1974@yahoo.com
}

Received: May 25, 2020

doi:10.5539/mas.v14n7p133
Accepted: June 22, 2020

Online Published: June 30, 2020

\begin{abstract}
It's a paper that studying money inflation that is an associated with the investment process and is noted to almost affect both Foreign Direct Investment (FDI) and domestic direct investment (DDI) simultaneously. Industrial development issues are often related to investment process in Jordan. The study highlights how financial inflation affects decisions of investment of most industrial companies in Jordan. Through this study future studies will be conducted with the conceptual structure of investment decisions through monetary inflation as a shape of capital, commodities, and import inflation in Jordanian industrial companies. To acquire the important information that helped to justify the study hypothesis, a question. To confirm the direct investment decisions and inflation relationship, Pearson's Correlation Test formula was used in this analysis. The entire results found: the lowest coefficient was in the overall correlation coefficient for imported inflation and the reserved variables. It was noted that when other variables decrease, the rising in most imported inflation might be compensated. In other hand, the remaining variables' correlation coefficient had a positive value.
\end{abstract}

Keywords: inflation, monetary inflation, investment, investment decisions

\section{Introduction}

Inflation is a common economic phenomenon of the world countries characterized by prices increasing by an increasing level. This incessant level increasing of the price has encouraged economic researchers to conduct studies to explore its causes through in-depth studies. The inflation impact on the economy of two-level after five decades of crisis still continues to appear. Inflation has been observed to often affect all monetary and economic fundamentals, including monetary and economic theories that crystallize based on location, impact, and time. Therefore, high inflation level and devaluation often strongly affects the economy that may affect long-term and short-term investment decisions of most organizations. However, most investments aim to increase profits and maximize, and about inflation event, they are threatened with bankruptcy and outcome interest loss (Al-Shabib, 2018). Inflation reduces the power of purchasing of currency upon Investment decisions of Jordanian industrial companies (Al-Rawi, 1999).

Presently, the persistent rise in the inflation and prices are the leading causes of many problems that individuals or companies may face especially individual consumers and industrial companies. Therefore, their decisions of investment affect the thrive, profits and continuity of their businesses. Therefore, the paper indicates how inflation, capital, and imported inflation has an effect on various products in the Jordanian industrial companies.

\subsection{The Study Importance}

The monetary inflation effect on the investment decisions of Jordanian industrial companies are indicated in the study. This study is aiming to contribute and strengthen current literature with the framework of decisions of investment using monetary inflation, that is interpreted by capital, goods and inflation imports in Jordan industrial companies. According to researcher knowledge, this paper has not been effectively resolved by previous research. Therefore, this paper will be a scientific resource for the future studies. 


\section{Literature Review}

\subsection{Inflation}

It's not s specific economic concept, because no contracts are between competent agencies which can be the correct definition. It is worthy to notice that the inflation concept is counted through many cases and observations that are considered independent of other factors. However, this independence confuses defining this concept.

Inflation is the sustained increasing of the whole price level. This reflects increasing in cash circulation without associated increase of services and goods amount (Fase \& Folkertsma, 1996, p.49). It is a continuous increase in public price levels (Friedman, 1960). It is known as the state of high cash income such as wages or profits (Mishkin, 2007). Generally, depending on currency devaluation nature, prices like to increase. Furthermore, by definition it's a continuous upward movement of prices that leads to their rise resulting in more demand than supply (Galí, 2015).

However, the researcher considers inflation as a general rise in the price level, which makes a large gap between goods amount and expenses based on income levels.

\subsection{Characteristics of Inflation}

Inflation is characterized generally by high prices. This nature of rise in price level is however not precise. Vestin (2006) indicated that this increase may be irregular (Vestin, 2006). Some writers also believe that the inflation is a state of a constant movement of high prices in the markets. Moreover, inflation can be movement of private price level and public one upwards coupled with persistent decrease in purchasing power (Evans, 2012). Inflation can involve a dual content of that theory that is; an unusual rise in level of price or the general price movement caused by the currency cash element as main driving force.

\subsection{Types of Inflation}

Many types of inflation share common links and are characterized according to various criteria that define the concept of inflation as an economic phenomenon. Therefore, the types of inflation can be discussed in many different classifications, which are classified by the Valley et al. (2014) and Brigo and Mercurio (2007).

\subsubsection{Commodity Inflation}

This is an inflation of products that is highly profitable in these commodities' industry (Yassin, 2005). This inflation type is observed by the commodities production as it's caused by a rise in the consumption expenditures rather than savings (Dawood, 2001, p.201).

\subsubsection{Capital Inflation}

This inflation type shows a rise in the goods value invested against their costs of production and their outcomes during the outbreak of these inflationary trends, it includes the immediate sustainable profits achieved in consumption sector and investment (Gujjani, 2011)

Also, investment goods will experience high profits in the commodity manufacturing industries during this inflation type through investment (Bernholz, 2015).

\subsubsection{Import Inflation}

This inflation type is caused majorly by the increasing in prices as a reflection of the inflation flow in the world through imports. Therefore, services and goods exported to country are influenced by inflation and it's passed on to goods and services of other countries (Raj \& Jain, 2008). Inflation here is associated with foreign trade transactions and it causes the worker to demand a corresponding rise in their salaries and wages. Therefore, this increase becomes an effective demand (Nell, 2004).

\subsection{Investment Concepts}

The investment concept, by definition, is benefit that is expected over a time period by the proper utilization of existing assets and funds (Aivazian et al., 2005). Investment has multiple definitions in science of finance and economy. It's possible to refer to investment as physical assets acquisition through the funds use and the impact of its utilization in the process production (Yahya, 2001, p.8).

In Economic terms Investment is defined as the injection of capital funds in a current project whether it is for production services or renewal and modernization to obtain a future return or benefit, (Al-Shabib, 2018, p.14))

Investment in macroeconomics implies the efficient allocation of existing economic resources with the following concepts (Blaug, 1997):

First concept: investment is the financial security assets purchase like stocks plus bonds. 
Second concept: Is the capital goods or assets purchase, such as machinery or equipment, which is considered as the origin and tools for the goods production.

The investment concept is usually considered by businessmen and executives as the physical assets and financial assets purchase. Investment through the capital use is very significant as against investment via financial instruments (Brealey et al., 2012, p.54). Investment can be defined as postponing the financial instruments use for future periods and then use these funds for investment, employment, and development instead of accumulating or hoarding (Tirole, 2010).

The concept of investing in financial principles can be effective employment of capital which is achieved by channeling the savings use in activities which leads to goods or services creation aimed at meeting the members of society economic needs and achieving prosperity (Shukairi et al., 2016).

Therefore, investing in a modern concept is the optimal utilization of tangible financial assets in activities that will generate profits and money from them. Investments are done to obtain tangible and intangible cash flow to compensate for unforeseen future risks.

\subsection{The Purpose and Importance of Investment}

The principal purpose of an investment is the need for individuals, groups, and organizations to generate future returns to increase wealth and finance unforeseen events (Al-Rawi, 1999, p.89; Al-Shabib, 2018). Investment results that aimed at creating wealth and development are considered using financial and economic methods after the fund is sacrificed.

Some researchers believe that investment is related to (Shakiri et al., 2016):

1- Sacrificing funds, cash and other assets

2 - The possibility of receiving future returns is unpredictable

3 - The need for more cash

\subsection{Investment Decision}

Investment decisions affect the organization future, it is the hardest decisions investors of various establishments and organizations have to face. Some disadvantages of investment decisions are its dependency on the organization's expectations, objectives, activities, and policies (Saunders \& Cornett, 2003). Investment decisions are influenced by available data accuracy and environment to reach a remarkable result. This is one of the most important bases for making precise investment decisions. Accurate and Good information is got from accurate and well-prepared information (Al-Rawi, 1999, p.32).

\subsection{Types of Investment Decisions}

There are many investment decisions types made by institutions that are different in type and the investment duration. Investment decision is an important foundation in the organizations work, establishments and economic units of all types and forms. In general, it's divided to two parts:

\subsubsection{Direct Investment Decision}

These are real investment decisions made by real assets purchase such as real estate and land, imported goods, machinery and other things in various companies. This investment means the assets acquisition with additional economic value and economic benefits such as manufacturing of a product (Hou et al., 2015). It also involves companies that make direct decisions to obtain maximum profits when at risk and other inflationary phenomena. The real concept of these decisions is to achieve wealth as the main objective which is considered "Direct investment" or "project". Therefore, direct investment decisions include direct investments in all areas, whether local or external (Dawood, 2016).

\subsubsection{Indirect Investment Decisions}

This includes institutions that possess certain assets that are intangible and are not real when presented as stocks or bonds or certificates of deposit, etc. (Turvey, 2017, p.149).

\section{Previous Studies}

\subsection{Geofrey T. Mills (1996), Titled: The Impact of Inflation on Capital Budgeting and Working Capital}

This article describes how the inflation affects the capital budgeting process. From the study, Capital costs tend to directly proportionate to the rate of inflation on a one-time basis thereby causing a multiplier effect. this article found that a significant degree of net working capital as a proportion of the overall capital needed. This leads to that the effect of inflation on capital expenditure can be greater as the net working capital is higher. 
3.2 Cizkowicz and Andrzej Rzońca (2013), Title: Does Inflation Harm Corporate Investment? Empirical Evidence from OECD Countries

Studying the period 1960 to 2005, the researchers examined the relationship between inflation and corporate investment, using 21 countries that are OECD members as the study sample. The study indicates that investment and inflation are significantly negatively related. They suggested that non-linear relationship of product growth and inflation comes from non-linear relationship of investment plus inflation. Therefore, the central bank can use this negative behavior during the slowdown by extending the economic recovery period.

\subsection{Konstantinos Garoufalis (2017), Title: Investment Decisions and Inflation}

This is a paper of adopts the investment assessment techniques in addressing the issue of inflation. Normally, investment involves cash outcomes, followed by benefits from cash and inflation that will raise level of current price by an amount that increases over time. The study said that impact of not addressing the inflation problem on investment is significant. However, addressing the inflation problem in the process of assessment serves as proxy allowance for factors known as risks.

3.4 Noura Abu Asab and Alaaeddin Al-Tarawneh (2018), Title: The Impact of Inflation on Investment: The Non-Linear Nexus and Inflation Threshold in Jordan

This research highlights non-linear relationship that is between inflation and investment in most manufacturing industries in Jordan. Using threshold model from 1980-2016, the research found that investment can be withdrawn when rates of inflation are not favorable (inflation is above $10 \%$ level). For the investment sustainability, the inflation rates must be less than (10\%).

\section{Study Model and Hypotheses}

By the problem of study and literature mentioned above, including some previous research, the researcher prepared the following study models. As showed in Figure 1, researchers propose a study model to close the gap.

\begin{tabular}{|l|l|}
\hline$\{$ Independent $\}$ Variable & $\{$ Dependent $\}$ Variable \\
\hline Monetary Inflation: & Investment Decisions: \\
-Direct Investment Decisions & -Capital Inflation \\
-Indirect Investment Decisions & - Commodity inflation \\
& - imported inflation \\
\hline
\end{tabular}

Figure 1. Study model

Table 1. Study Variables

\begin{tabular}{cccc}
\hline Variables & Dimensions & No. of Questions & References \\
\hline $\begin{array}{c}\text { Independent Variable } \\
\text { Inflation } \\
\text { Independent Variable } \\
\text { Inflation }\end{array}$ & Capital Inflation & $13-18$ & Ireland, 2009 \\
Independent Variable & Commodity inflation & $7-12$ & Yassin, 2005 \\
Inflation & Imported inflation & $1-6$ & Raj et al., 2008 \\
$\begin{array}{c}\text { Dependent Variable } \\
\text { Investment Decisions } \\
\text { Dependent Variable } \\
\text { Investment Decisions }\end{array}$ & $\begin{array}{c}\text { Capital Inflation } \\
\text { Indirect Investment } \\
\text { Decisions }\end{array}$ & $19-24$ & Duflo \& Saez, 2002 \\
\hline
\end{tabular}

Source: Prepared by researcher

\section{Method and Procedures}

\subsection{Study Methodology}

The monetary inflation impact in the decisions of investment is mentioned in the study. The industrial organizations in Amman Stock Exchange list was the study field. Descriptive analysis method was used to achieve the study aim. The descriptive approach is also adopted to represent study variables' theoretical framework. The 
approach used in analysis is depending on regression plus correlation variables result the study. These variables were derived from study samples responses as obtained by the questionnaire.

\subsection{Demographics}

257 employees in 4 Jordan industrial companies were the overall population.50 employees were also selected as random sample.

Table 2. Questionnaires distributed, retrieved, and valid for the statistical analysis

\begin{tabular}{cccc}
\hline Study Sample & $\begin{array}{c}\text { Number of Questionnaires } \\
\text { distributed }\end{array}$ & $\begin{array}{c}\text { Number of Retrieved } \\
\text { questionnaires }\end{array}$ & $\begin{array}{c}\text { Valid questionnaires for } \\
\text { statistical analysis }\end{array}$ \\
\hline Workers & 50 & 45 & 40 \\
\hline
\end{tabular}

Source: Prepared by the researcher

\subsection{Study Tool}

for collection of data needed to verify study hypotheses, a questionnaire consisting of some paragraphs was designed as follows:

Independent Variable: the monetary inflation is measured using the three dimensions

First Dimension: Imported inflation and paragraphs (1-6)

Second Dimension: Commodity inflation and guarantees paragraphs (7-12)

The third Dimension: Capital inflation, paragraphs (13-18)

Dependent Variable: Investment decisions

The First Dimension: Direct decisions and paragraphs (19-24)

Second Dimension: Indirect decisions, paragraphs (25-30)

The Likert Scale is used for determination of level of response. This scale is easy plus widely used to know methods of determining of response level, and it is as: 1-5, with 1 still not fully agreed, 5 fully agreed. The importance level for the responses' computational locality was determined using the equation:

5-1 / $3=1.33$ and then distributed as: 1-2.33 Poor, 2.34-3.66 average, 3.67 -5 high

\subsection{Tool Reliability and Stability}

About study validity, questionnaires group was presented to experts' group who were guided by their views in the paragraphs ability to measure variables. To confirm the responses 'consistency in the sampling units, the Cronbach Alpha value was calculated. The overall ratio of response stability to questionnaire paragraph was $86.4 \%$, which exceeded the acceptable minimum rate.

Table 3. Stability coefficient in the variables of study (Alpha Cronbach Scale)

\begin{tabular}{|c|c|c|c|c|c|c|}
\hline Variables & $\begin{array}{l}\text { Imported } \\
\text { inflation }\end{array}$ & $\begin{array}{l}\text { Commodity } \\
\text { inflation }\end{array}$ & $\begin{array}{l}\text { Capital } \\
\text { Inflation }\end{array}$ & $\begin{array}{c}\text { Direct } \\
\text { Investment } \\
\text { Decisions }\end{array}$ & $\begin{array}{c}\text { Indirect } \\
\text { Investment } \\
\text { Decisions }\end{array}$ & $\begin{array}{c}\text { General } \\
\text { stability rate }\end{array}$ \\
\hline $\begin{array}{c}\text { Alpha } \\
\text { Kronbach }\end{array}$ & 0.77 & 0.89 & 0.613 & 0.865 & 0.821 & 0.864 \\
\hline
\end{tabular}

\section{Conclusions and Recommendations}

\subsection{Results}

First: In ascertaining study variables relationship, Pearson correlation coefficient was extracted among all study variables as shown within table below. 
Table 4. Coefficient of Pearson correlation in study variable

\begin{tabular}{cccccc}
\hline & $\begin{array}{c}\text { Imported } \\
\text { inflation }\end{array}$ & $\begin{array}{c}\text { Commodity } \\
\text { inflation }\end{array}$ & $\begin{array}{c}\text { Capital } \\
\text { Inflation }\end{array}$ & $\begin{array}{c}\text { Direct } \\
\text { Investment } \\
\text { Decisions }\end{array}$ & $\begin{array}{c}\text { Indirect } \\
\text { Investment } \\
\text { Decisions }\end{array}$ \\
\hline Pearson Correlation & 1 & & & & \\
Sig. (2-tailed) & & & & \\
Pearson Correlation & -.446 & 1 & & \\
Sig. (2-tailed) & .004 & & & \\
& & & & \\
Pearson Correlation & -.233 & $.406^{* *}$ & 1 & \\
Sig. (2-tailed) & .147 & .009 & & \\
Pearson Correlation & -.142 & $.676^{* *}$ & $.555^{* *}$ & 1 \\
Sig. (2-tailed) & .381 & .000 & .000 & \\
Pearson Correlation & -.120 & $.419^{* *}$ & $.561^{* *}$ & $.601^{* *}$ & \\
Sig. (2-tailed) & .460 & .007 & .000 & .000 &
\end{tabular}

The inflation and direct investment decisions relationship is placed in the above table with Pearson (676) and levels with statistical significance $(0.00)$. on other hand, the lowest coefficient is observed that all (correlation coefficient) between inflation at Import and remaining variables are reversed. Therefore, any increase in imported inflation can be compensated by the reduction of other variables. On other hand, the remaining (correlation coefficient) between variables are positive.

\subsection{Hypothesis}

Key assumptions: At $(\alpha=0.05)$ significance level, the impact of inflation in its dimension (Capital inflation, commodities, imported inflation) isn't statistically significant on investment decisions expressed in direct plus indirect decisions of investment and in Jordanian industrial companies.

The main hypothesis is from the coming assumptions:

1- First hypothesis: impact of capital inflation in investment decisions in their dimensions (Direct investment decisions, indirect decisions of investment) at significance level $(\alpha=0.05)$ isn't statistically significant in the companies of industry of Jordan.

2- Second sub-hypothesis: impact of commodity inflation in investment decisions in their dimensions (Direct investment decisions, indirect decisions of investment) at significance level $(\alpha=0.05)$ isn't statistically significant in the companies of industry of Jordan.

3- The third sub hypothesis: impact of imported inflation in investment decisions in their dimensions (Direct investment decisions, indirect decisions of investment) at significance level $(\alpha=0.05)$ isn't statistically significant in the companies of industry of Jordan.

\subsubsection{Hypothesis Testing}

The multiple regression tests result at statistical significance at 0.05 is:

The main hypothesis testing results reveal that impact of financial inflation in investment decisions in their dimensions (direct investment) at significance level $(\alpha=0.05)$ isn't statistically significant in an ASE registered company in Jordan, excluding import inflation, commodity inflation, and capital inflation. 
Table 5. Regression test results for sample responses on paragraphs associated with the main hypothesis

\begin{tabular}{|c|c|c|c|c|c|c|c|c|}
\hline \multicolumn{9}{|c|}{ Coefficients } \\
\hline & \multirow[t]{2}{*}{ Model } & \multicolumn{2}{|c|}{$\begin{array}{c}\{\text { Unstandardized } \\
\text { Coefficients }\}\end{array}$} & \multirow{2}{*}{$\begin{array}{c}\{\text { Standardized } \\
\text { Coefficients }\} \\
\text { Beta }\end{array}$} & \multirow[t]{2}{*}{$\mathrm{T}$} & \multirow[t]{2}{*}{ Sig. } & \multirow[t]{2}{*}{$\mathrm{F}$} & \multirow[t]{2}{*}{ Sig } \\
\hline & & B & Std. Error & & & & & \\
\hline \multirow{4}{*}{1} & (Constant) & -.273 & .849 & & -.322 & .750 & & \\
\hline & Imported inflation & .230 & .152 & .186 & 1.519 & .138 & 15.764 & \\
\hline & Capital inflation & .544 & .142 & .462 & 3.844 & .000 & & 0.000 \\
\hline & $\begin{array}{l}\text { Commodity } \\
\text { inflation }\end{array}$ & .486 & .126 & .504 & 3.863 & .000 & & \\
\hline & & & & $\mathrm{R} 2: 0.5$ & & & & \\
\hline
\end{tabular}

In Table 5, the f value of reached 15.764 and the statistical significance level is up to 1,000 , which indicates rejection of the null hypothesis. This leads to that the impact isn't statistically significant at the significance level $(\alpha=0.05)$ of Commodity inflation and Capital inflation on investment decisions in their dimensions (direct investment, indirect investment) in an industrial company in Jordan included in Amman Stock Exchange list

This result means that the monetary inflation effect in all dimensions on decisions of investment making is a statistically significant. Decision making analysis of the coefficient is, up to $56.8 \%$ of the dependent variable variance in the (investment decision) illustrated by the imported inflation value.

1-First Sub-hypothesis Test Result: The result indicates that the impact of imported inflation in its dimension on investment decisions (direct investment, indirect investment) isn't statistically significant at significance level $(\alpha=$ 0.05). In the industrial company in Jordan listed in the Amman stock exchange.

Table 6. Simple regression test of sample responses on the paragraphs associated with the first sub-hypothesis

\begin{tabular}{|c|c|c|c|c|c|c|}
\hline \multicolumn{7}{|c|}{ Coefficients } \\
\hline & \multirow{2}{*}{ Model } & \multicolumn{2}{|c|}{ Unstandardized Coefficients } & \multirow{2}{*}{$\begin{array}{c}\text { Standardized } \\
\text { Coefficients } \\
\text { Beta }\end{array}$} & \multirow[t]{2}{*}{$\mathrm{T}$} & \multirow{2}{*}{ Sig. } \\
\hline & & B & Std. Error & & & \\
\hline \multirow[b]{2}{*}{1} & (Constant) & 4.489 & .676 & & 6.644 & .000 \\
\hline & $\begin{array}{l}\text { Imported } \\
\text { Inflation }\end{array}$ & -.181 & 198 & -.146 & -.913 & .367 \\
\hline
\end{tabular}

a. Dependent Variable: Investment Decisions

In Table 6 above, the $t$ values of reached -913 and the statistical significance level is 0.367 , this reflects that the impact isn't statistically significant at level of significance $(\alpha=0.05)$. No significant impact of the null hypothesis at the significance level $(\alpha=0.05)$ of import inflation on decisions of investment in all its dimensions (direct investment, indirect investment) in the industrial corporation listed on the Amman Stock Exchange in Jordan is accepted.

2-Second Sub-hypothesis Test Result: Impact of commodity inflation on decisions of investment in its dimensions (direct investment, indirect investment) at the significance level $(\alpha=0.05)$ isn't statistically significant in industrial company in Amman stock exchange List in Jordan. 
Table 7. Results of simple regression test for sample responses on paragraphs associated with the second sub-hypothesis

\begin{tabular}{|c|c|c|c|c|c|c|}
\hline \multicolumn{7}{|c|}{ Coefficients } \\
\hline & \multirow[t]{2}{*}{ Model\} } & & $\begin{array}{l}\text { lardized } \\
\text { ients }\end{array}$ & $\begin{array}{l}\{\text { Standardized } \\
\text { Coefficients }\end{array}$ & \multirow[t]{2}{*}{$\mathrm{T}$} & \multirow[t]{2}{*}{ Sig. } \\
\hline & & B & Std. Error & Beta & & \\
\hline \multirow[b]{2}{*}{1} & (Constant) & 1.854 & .432 & & 4.287 & .000 \\
\hline & $\begin{array}{l}\text { commodity } \\
\text { inflation }\end{array}$ & .587 & .124 & 609 & 4.733 & .000 \\
\hline
\end{tabular}

a. Dependent Variables: investment decisions

In Table 7, the $t$ value of reached 4.733 and statistical significance level is 0.000 . This means the impact at a level of significant $(\alpha=0.05)$ is statistically significant. Therefore, this leads to that no significant impact at the significance level $(\alpha=0.05)$ of null hypothesis has for commodity inflation on investment decisions by dimensions (direct investment, indirect investment) in the industrial corporation in the Amman stock exchange list in Jordan. Therefore, the impact of alternative hypothesis which is accepted is significant at the significance level $(\alpha=0.05)$ of commodity inflation on investment decisions in Jordanian Industrial companies registered in ASE.

3-Third Sub-hypothesis Test Result: Impact of capital inflation on the investment decisions in all its dimensions (Direct investment, indirect investment) isn't statistically significant at the significance level $(\alpha=0.05)$ in the Industrial companies in Jordan listed in Amman stock exchange.

Table 8. Results of the simple regression test of sample responses on paragraphs associated with the third sub-hypothesis

\begin{tabular}{|c|c|c|c|c|c|c|}
\hline \multicolumn{7}{|c|}{ Coefficients } \\
\hline & \multirow{2}{*}{ Model\} } & \multicolumn{2}{|c|}{ Unstandardized Coefficients } & \multirow{2}{*}{$\begin{array}{c}\text { \{Standardized } \\
\text { Coefficients }\} \\
\{\text { Beta }\{\end{array}$} & \multirow{2}{*}{$t$} & \multirow{2}{*}{ Sig. } \\
\hline & & $\{B\}$ & $\{$ Std. Erro $\} \mathrm{r}$ & & & \\
\hline \multirow[b]{2}{*}{1} & $\{$ Constant & 1.589 & .470 & & 3.381 & .002 \\
\hline & $\begin{array}{l}\text { Capital } \\
\text { Inflation }\end{array}$ & .734 & .149 & .623 & 4.914 & .000 \\
\hline
\end{tabular}

a. Variable: Investment Decisions

In Table 8 , the $t$ value of reached 4.914 and statistical significance level is 0.000 and it's statistically significant at significant level. This leads to that null hypothesis is not accepted, indicating that impact isn't significant at significance level $(\alpha=0.05)$ for capital inflation on investment decisions with their dimensions (direct and indirect investment) in an industrial company in the Amman Jordan Stock Exchange list. At significance level $0.05 \alpha$, the impact of capital inflation on investment decisions is statistically significant in ASE listed companies.

\subsection{Recommendations}

The results found by this study suggest as follows recommendations:

- Investors should be educated on imported inflation plus their effect in national inflation.

- States should reduce imported inflation by supporting local industries and encouraging the local materials use obtained locally for production.

- a future study must be done on the import inflation and other types that made from the raised cost of importing raw materials from other world countries.

- Focusing on future studies that show inflation in Jordan.

\section{References}

Abele, E., Liebeck, T., \& Wörn, A. (2006). Measuring flexibility in investment decisions for manufacturing $\begin{array}{llll}\text { systems. } & \text { CIRP } P \text { Annals-Manufacturing }\end{array}$ https://doi.org/10.1016/S0007-8506(07)60452-1

Aharoni, Y. (2015). The foreign investment decision process. In International Business Strategy, 24-34. 
Routledge.

Aivazian, V. A., Ge, Y., \& Qiu, J. (2005). The impact of leverage on firm investment: Canadian evidence. Journal of corporate finance, 11(1-2), 277-291. https://doi.org/10.1016/S0929-1199(03)00062-2

Al-Rawi Khalid. (1999). Investment Concepts of Strategic Analysis, 1, Baghdad: Al-Muthanna Press.

Al-Shabib Duraid. (2018). Financial and Monetary Markets, 2, Amman: Dar Al-Masirah for Publishing and Distribution.

Bade, R., \& Parkin, M. (2007). Foundations of economics. Pearson/Addison Wesley.

Bernanke, B. S., Laubach, T., Mishkin, F. S., \& Posen, A. S. (2018). Inflation targeting: lessons from the international experience. Princeton University Press. https://doi.org/10.2307/j.ctv301gdr

Bernholz, P. (2015). Monetary Regimes and Inflation: History, economic and political relationships. Edward Elgar Publishing. https://doi.org/10.4337/9781784717636

Billi, R. M., \& Kahn, G. A. (2008). What is the optimal inflation rate? Economic Review-Federal Reserve Bank of Kansas City, 93(2), 5.

Blaug, M. (1997). Economic theory in retrospect. Cambridge university press. https://doi.org/10.1017/CBO9780511805639

Brealey, R. A., Myers, S. C., Allen, F., \& Mohanty, P. (2012). Principles of corporate finance. Tata McGraw-Hill Education.

Brigo, D., \& Mercurio, F. (2007). Interest rate models-theory and practice: with smile, inflation and credit. Springer Science \& Business Media.

Bryan, M. F., \& Pike, C. J. (1991). Median price changes: an alternative approach to measuring current monetary inflation. Federal Reserve Bank of Cleveland Economic Commentary, 1. https://doi.org/10.26509/frbc-ec-19911201

Damodaran, A. (1996). Corporate finance. Wiley.

David Hossam. (2016). Principles of Macroeconomics, 5, Amman: Dar Al Masirah for Publishing and Distribution.

De Grauwe, P. (2018). Economics of monetary union. Oxford university press.

Dornbusch, R., \& Fischer, S. (1993). Moderate inflation. The World Bank Economic Review, 7(1), 1-44. https://doi.org/10.1093/wber/7.1.1

Duflo, E., \& Saez, E. (2002). Participation and investment decisions in a retirement plan: The influence of colleagues' choices. Journal of public Economics, $85(1), \quad$ 121-148. https://doi.org/10.1016/S0047-2727(01)00098-6

Evans, C. L. (2012). Monetary Policy in a Low-Inflation Environment: Developing a State-Contingent Price-Level Target. Journal of Money, Credit and Banking, 44(s1), 147-155. https://doi.org/10.1111/j.1538-4616.2011.00482.x

Fase, M. M. G., \& Folkertsma, C. K. (1996). Measuring inflation: an attempt to operationalize Carl Menger's concept of the inner value of money. De Nederlandsche Bank NV.

Friedman, M. (1960). A program for monetary stability (Vol. 541). New York: Fordham University Press.

Friedman, M. (2017). Quantity theory of money.The New Palgrave Dictionary of Economics, 1-31. https://doi.org/10.1057/978-1-349-95121-5_1640-1

Galí, J. (2015). Monetary policy, inflation, and the business cycle: an introduction to the new Keynesian framework and its applications. Princeton University Press.

Gasperini, M., \& Veneziano, G. (1993). Inflation, deflation, and frame-independence in string cosmology. Modern Physics Letters A, 8(39), 3701-3713. https://doi.org/10.1142/S0217732393003433

Gavin, W. T., \& Stockman, A. C. (2016). Why a Rule for Stable Prices May Dominate a Rule for Zero Inflation. Small, $11,17$.

Geofrey T. Mills. (1996). THE IMPACT OF INFLATION ON CAPITAL BUDGETING AND WORKING CAPITAL. Journal of Financial and Strategic Decisions, 9(1).

Gujiani Aus. (2011). Inflation, Uncertain Inflation and Monetary Policy. Rafidain Development Journal, 103(33), 
110-129. https://doi.org/10.33899/tanra.2011.161946

Harris, D. J., \& Froufe, E. (2005). Taxonomic inflation: species concept or historical geopolitical bias? Trends in Ecology \& Evolution, 20(1), 6-7. https://doi.org/10.1016/j.tree.2004.11.004

Hindi Mounir. (2006). Securities and Money Markets, 1, Mosul: Dar Kun for Printing and Publishing.

Hou, K., Xue, C., \& Zhang, L. (2015). Digesting anomalies: An investment approach. The Review of Financial Studies, 28(3), 650-705. https://doi.org/10.1093/rfs/hhu068

Ireland, P. N. (2009). On the welfare cost of inflation and the recent behavior of money demand. American Economic Review, 99(3), 1040-52. https://doi.org/10.1257/aer.99.3.1040

Jarr, B. (2017). Economics, Business, Social Sciences \& Education Vol Xvi (1).

Keynes, J. M. (2018). A tract on monetary reform. Pickle Partners Publishing.

Konstantinos Garoufalis. (2017). Investment Decisions and Inflation.

Leeper, E. M., \& Leith, C. (2016). Understanding inflation as a joint monetary-fiscal phenomenon. In Handbook of Macroeconomics, 2, 2305-2415. Elsevier. https://doi.org/10.1016/bs.hesmac.2016.03.012

Li, H., \& Zou, H. F. (2002). Inflation, growth, and income distribution: A cross-country study. Annals of Economics and Finance, 3(1), 85-101.

Mclachlan, C., Shore, L., \& Weiniger, M. (2017). International investment arbitration: substantive principles.

Mishkin, F. S. (2007). Monetary policy strategy. Mit press. https://doi.org/10.7551/mitpress/7412.001.0001

Mohr, P. (2005). Economic indicators. Unisa Press.

Nashi Razak. (2014). Analysis of some economic variables on the rates of inflation in the Iraqi economy for the period 2003-2010. Muthanna Journal of Administrative Sciences and Economic, 4(8), 121-144.

Neely, C. J., \& Rapach, D. E. (2011). International comovements in inflation rates and country characteristics. Journal of International Money and Finance, 30(7), 1471-1490. https://doi.org/10.1016/j.jimonfin.2011.07.009

Nell, K. S. (2004). The structuralist theory of imported inflation: an application to South Africa. Applied Economics, 36(13), 1431-1444. https://doi.org/10.1080/0003684042000204467

Noura Abu Asab., \& Alaaeddin Al-Tarawneh. (2018). The Impact of Inflation on Investment: The Non-Linear Nexus and Inflation Threshold in Jordan. Modern Applied Science, 12(12). https://doi.org/10.5539/mas.v12n12p113

Omar Hussein. (2000). Investment and Globalization, 1, Cairo: Modern Book House.

Phelps, E. S. (1970). Microeconomic foundations of employment and inflation theory.

Pike, R., \& Neale, B. (2006). Orporate finance and investment: decisions \& strategies. Pearson Education.

Raj, J., Dhal, S., \& Jain, R. (2008). Imported inflation: The evidence from India. Reserve Bank of India Occasional Papers, 29(3), 69-117.

Romer, D. (1993). Openness and inflation: theory and evidence. The quarterly journal of economics, 108(4), 869-903. https://doi.org/10.2307/2118453

Saunders, A., \& Cornett, M. M. (2003). Financial institutions management: A risk management approach. Irwin/McGraw-Hill.

Shukairi, Nuri., Zarkan, Saleh., Aldwikat, Fayez., \& Haddad, handsome. (2016). Investment Management, 2, Amman: Dar Al Masirah for Publishing and Distribution.

Taylor, J. B. (2000). Low inflation, deflation, and policies for future price stability. IMES.

Taylor, L. (1991). Income distribution, inflation, and growth: lectures on structuralist macroeconomic theory. mit Press.

Thierer, A. (2013). Techno panics, threat inflation, and the danger of an information technology precautionary principle. Minn. L Sci. \& Tech., 14, 309. https://doi.org/10.2139/ssrn.2012494

Tirole, J. (2010). The theory of corporate finance.Princeton University Press.

Turvey, R. (2017). Optimal Pricing and Investment in Electricity Supply: An Esay in Applied Welfare Economics. Routledge. https://doi.org/10.4324/9781315144207 
Vestin, D. (2006). Price-level versus inflation targeting. Journal of Monetary Economics, 53(7), 1361-1376. https://doi.org/10.1016/j.jmoneco.2005.07.015

Wadi, Mahmoud., Assaf, Ahmed., \& Safi, Walid. (2014). Macroeconomics, 4, Amman: Dar Al Masirah for Publishing and Distribution.

Yahya Dawood. (2001). Critical Theory, 2, Mosul: Dar Al Kutub for Printing and Publishing.

Yassin Zuhair. (2005). The Effect of Inflation on the Evaluation of Al-Mahzoun in Economic Establishments. Journal of Baghdad College of Economic Sciences, University, 10(1), 220-244.

Yellen, J. (2015). Inflation dynamics and monetary policy. Speech delivered at the Philip Gamble Memorial Lecture, University of Massachusetts, Amherst, Amherst, Mass., September, 24.

\section{Copyrights}

Copyright for this article is retained by the author(s), with first publication rights granted to the journal.

This is an open-access article distributed under the terms and conditions of the Creative Commons Attribution license (http://creativecommons.org/licenses/by/3.0/). 